\title{
KEMELIMPAHAN DAN AKTIVITAS MENGGIGIT NYAMUK Aedes Sp PADA DAERAH ENDEMIS DEMAM BERDARAH DENGUE DI KOTA METRO, LAMPUNG
}

\author{
Suharno Zen \\ Pendidikan Biologi FKIP Universitas Muhammadiyah Metro \\ E-mail: suharnozein@gmail.com
}

\begin{abstract}
Aedes sp mosquitoes as vectors of disease Dengue fever remains a serious health problem in Indonesia. This research is important to be studied because by knowing the abundance and activity of the mosquito bite would help in early warning and the work were done as a form of prevention / preventive direct contact with mosquitoes. The research was conducted in the Village Metro District of Metro Center on RT 09, RT 11 and RT 10. RT 12. Catching adult mosquitoes do 1 time per week in the month of April 2014 from the hours 06: 00-18: 00. The method used for catching mosquitoes is to use bait human foot (human landing) for 20 minutes. Results showed the peak activity occurred 2 times, ie at 09:00 to 9:55 and at 16:00 to 16:55 pm. Blood biting behavior of Aedes sp in Metro City is anthropophilic. Values for the relative abundance of fishing activity in the house (endofagik) of 7.28, while for fishing activities outside the home (eksofagik) 9.5.
\end{abstract}

Kata Kunci: Aedes sp, anthropofilik, human baiting.

Nyamuk Aedes sp sebagai
vektor penyakit DBD (Demam Berdarah Dengue) masih merupakan masalah kesehatan serius di Indonesia. Pada saat awal musim penghujan kemelimpahan nyamuk tersebut mulai meningkat. Hal ini salah satunya disebabkan oleh banyaknya genangangenangan air yang menjadi tempat berkembangbiak nyamuk. Nyamuk beraktifitas pada siang hari. Aktifitas mengigit biasanya mulai pagi sampai sore hari, antara jam 08.00-10.00 dan 15.00-17.00. Nyamuk betina Aedes aegypti mempunyai kebiasaan mengisap darah berulang kali dalam satu siklus gonotropik. Dengan demikian nyamuk ini sangat efektif sebagai penular penyakit. Nyamuk Aedes setelah mengisap darah, hinggap (beristirahat) di dalam rumah atau kadang-kadang di luar rumah berdekatan dengan tempat perkembangbiakannya. Biasanya di tempat yang agak gelap dan lembab. Di tempat-tempat ini nyamuk menunggu proses pematangan telurnya. (Gandahusada dkk, 2003).

Data yang diperoleh dari Dinas Kesehatan Kota Metro Tahun 2007 nilai IR (incident rate) sebesar ; 381/100.000. sedangkan nilai CFR (case fatality rate) sebesar ; 0,59\%.

Tahun 2008 nilai IR sebesar ; 460/100.000 sedangkan nilai CFR ; 0,96\%. Tahun 2009 nilai IR; $86 / 100.000$ sedangkan nilai CFR;3,39\%. Tahun 2010 IR; 83,06/ 100.000 sedangkan nilai CFR; $1,74 \%$. Tahun $2011 \quad$ IR;17,55 100.000 sedangkan nilai CFR; 0\%. Tahun 2012 terdapat penderita sebanyak 390 orang. Tahun 2013 tercatat terdapat 470 penderita. Tahun 2014 tercatat terdapat 146 penderita. Tahun 2014 tercatat terdapat 146 penderita. Sedangkan data terakhir bulan Januari - April tahun 2015 tercatat terdapat 254 penderita. Untuk angka bebas jentik (ABJ) tahun 2007 sebesar ; 92,47\%. Tahun 2008 ; $85,95 \%$. Tahun 2009; 85,95\% dan tahun 2010 sebesar ; 84,14\%. Angka 
tersebut menunjukkan masih tingginya kasus DBD khususnya di Kota Metro.

Penelitian

tentang

Kemelimpahan Dan Aktivitas

Menggigit Nyamuk Aedes Sp Pada

Daerah Endemis Di Kota Metro

Lampung belum pernah dilakukan sehingga atas dasar tersebut penelitian ini diusulkan. Penelitian ini penting untuk dikaji, karena dengan mengetahui kemelimpahan dan aktifitas menggigit nyamuk akan membantu upaya kewaspadaan dini dan usaha yang dilakukan sebagai bentuk pencegahan/preventif kontak langsung dengan nyamuk. Sehingga penularan virus Dengue manusia dapat dihindari. Data atau informasi yang diperoleh diharapkan dapat berguna bagi masyarakat dan pengambil kebijakan dalam kegiatan pengendalian nyamuk.

\section{METODE}

Penangkapan nyamuk dewasa dilakukan 1 kali seminggu dalam bulan April 2014 dari jam 06:00-18:00 sesuai dengan aktivitas nyamuk Aedes sp menggigit darah. Metode yang digunakan untuk penangkapan nyamuk adalah dengan menggunakan umpan kaki manusia (human landing) selama
20 menit, dan penangkapan nyamuk yang istirahat selama 5 menit di 4 wilayah RT (RT 09, RT 10, RT 11 dan RT 12) di Kelurahan Metro, Kecamatan Metro Pusat. Hal ini didasarkan data Dinas Kesehatan Kota Metro bahwa 4 RT tersebut jumlah kasus DBDnya paling tinggi. Penangkapan dilakukan 1 rumah per RT oleh peneliti dibantu dengan warga setempat dengan menggunakan alat aspirometer. Nyamuk kemudian dipindahkan ke paper cup yang diberi label (jumlah yang tertangkap, tanggal, lokasi, di dalam atau di luar rumah). Nyamuk yang diperoleh selanjutnya di bawa ke laboratorium biologi Universitas Muhammadiyah Metro untuk diidentifikasi. menggunakan kunci identifikasi larva dan nyamuk Aedes sp dari Departemen Kesehatan RI tahun 2008.

Rerata Nilai kelimpahan nisbi dianalisis menggunakan analisis deskriptif.

\section{HASIL}

Aktivitas Menggigit Nyamuk Aedes sp. dapat dilihat pada Gambar 1.

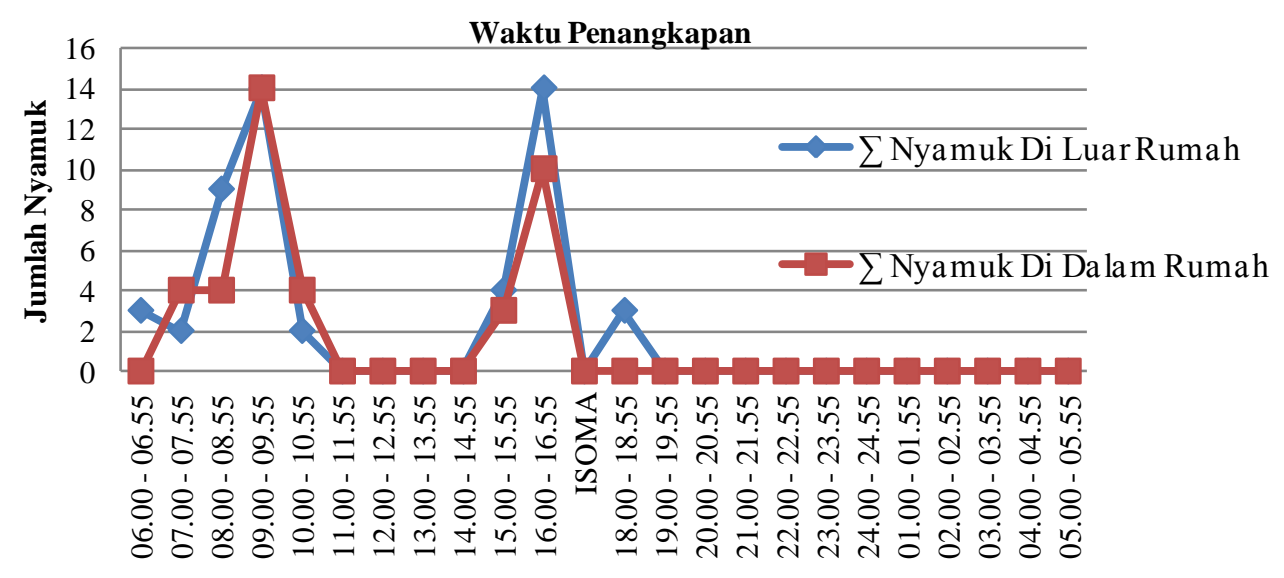

Gambar 1, Grafik Aktifitas Menggigit Nyamuk Aedes sp. di luar rumah dan di dalam rumah 
Tabel 1. Rerata Kelimpahan Nisbi

Nyamuk Aedes sp.

\begin{tabular}{|c|c|c|c|c|}
\hline \multirow{3}{*}{$\begin{array}{l}\text { Jenis } \\
\text { Nyamuk }\end{array}$} & \multicolumn{4}{|c|}{$\begin{array}{l}\text { Hinggap dengan umpan } \\
\text { manusia }\end{array}$} \\
\hline & \multicolumn{2}{|c|}{ Luar Rumah } & \multicolumn{2}{|c|}{$\begin{array}{l}\text { Dalam } \\
\text { Rumah }\end{array}$} \\
\hline & $\mathrm{Jml}$ & $\mathrm{KN}$ & $\mathrm{Jml}$ & $\mathrm{KN}$ \\
\hline Aedes sp. & 51 & 9,51 & 9 & 7,28 \\
\hline
\end{tabular}

\section{PEMBAHASAN}

Aktivitas nyamuk yaitu Aedes sp. sangat dipengaruhi oleh berbagai faktor. Dinas Kesehatan Kota Metro

Tempat-tempat yang demikian tentu sangat disukai oleh nyamuk, Hal ini diperkuat oleh pernyataan Sembel (2009) bahwa semua jenis nyamuk membutuhkan air untuk kelangsungan hidup karena larvalarva (jentik-jentik) nyamuk melanjutkan hidupnya di air dan hanya bentuk dewasa yang hidup di darat. Nyamuk Aedes sp. tidak beraktivitas disepanjang hari, artinya hanya pada jam-jam tertentu saja Aedes sp. melakukan aktivitas menggigit. Hasil dari penangkapan nyamuk beraktivitas mulai pukul 06.00 - 18.55 WIB.

Pada penelitian ini, diketahui bahwa puncak aktivitas nyamuk Aedes sp. terjadi dua kali, yaitu pertama pada pukul 09.00 - 09.55 WIB baik di luar maupun di dalam rumah. Hasil ini sesuai dengan pendapat Christophers, Hadi \& Koesharto (dalam Hadi, 2012) Aedes sp. aktif menghisap darah pada siang hari (diural) dengan dua puncak gigitan yaitu pagi hari jam 08.00 09.00 dan sore hari jam 16.00 17.00. Pada penelitian, antara pukul 11.00 - 14.55 WIB tidak ada nyamuk Aedes sp. yang menggigit kaki manusia dan artinya Aedes tidak melakukan aktivitas menggigit pada jam-jam tersebut, dengan kata lain dalam RPJMD Kota Metro tahun 2010 - 2015 menunjukkan bahwa Kepadatan penduduk Kota Metro tahun 2009 di daerah Metro Pusat sebanyak 4.162,08 jiwa/km². Faktor pendukung lain yang ditemukan yaitu adanya wadah-wadah atau botol-botol bekas yang mampu menampung air hujan, bak mandi yang jarang dikuras, dan pakaianpakaian yang digantung baik di teras rumah maupun di dalam rumah serta kebun dengan luas yang minim atau bahkan dalam kategori sempit.

nyamuk Aedes sp. sedang mengalami fase istirahat. Fase istirahat nyamuk Aedes sp. yang juga dijelaskan pada hasil penelitian sebelumnya oleh Sitio (2008) yang menyatakan bahwa Setelah menggigit selama menunggu waktu pematangan telur nyamuk akan berkumpul di tempat-tempat dimana terdapat kondisi yang optimum untuk beristirahat, setelah itu akan bertelur dan menggigit lagi. Puncak aktivitas yang kedua terjadi kembali ketika sore hari yaitu rentang waktu antara pukul 15.00 18.55 WIB. Supartha (2008) menyatakan Nyamuk Aedes aktif terbang pada sore hari antara pukul 15.00 - 17.00. Hasil lain dari penangkapan nyamuk menunjukkan bahwa pada pukul 18.00 - 18.55 WIB masih dijumpai nyamuk Aedes sp. yang aktif menggigit saat di luar rumah. Penelitian Hadi (2012) Di Babakan, Cikarawang dan Cibanteng kabupaten Bogor nyamuk Aedes dapat ditemukan menghisap darah di dalam rumah dan di luar rumah pada jam 18.00 hingga 20.50 WIB. Perilaku nyamuk dalam menghisap darah lebih menyukai dan hinggap di kaki manusia sebagai umpan (antropofilik), padahal di sekitar rumah terdapat hewan sapi dan kambing. Pada grafik 1. perilaku 
menghisap darah juga lebih sering dijumpai di luar rumah. Hal ini terlihat banyaknya nyamuk yang tertangkap di luar rumah yang dijadikan tempat penelitian banyak terdapat botol, bekas pot yang tergenang air dan ada jentik yang hidup di dalamnya. Hasyimi (2009) menyatakan salah satu penyebab tampungan air menjadi tempat berkembangbiak nyamuk Aedes sp adalah tidak tertutupnya penampungan air tersebut. Hal ini diperkuat juga oleh pendapat Supartha (2008) bahwa kebiasaan hidup imago Aedes sp. dapat berkembangbiak di tempat penampungan air bersih seperti bak mandi, tempayan, tempat minum burung dan barang-barang bekas yang dibuang sembarangan yang pada waktu hujan terisi air. Banyak dijumpai kasus di rumahtangga atau di bak mandi yang tidak digunakan masih tertinggal air sehingga memungkinkan untuk menjadi tempat berkembangbiak potensial Aedes sp (Veridiana, dkk. 2008). Dengan perilaku nyamuk di atas dapat dilakukan langkah preventif dalam hal menjaga kontak langsung dengan nyamuk, mengingat nyamuk lebih menyukai dan mencari mangsa manusia pada siang hari saat aktivitas manusia berlangsung.

Pada pengukuran temperatur ruangan di lokasi penangkapan berkisar antara $27^{\circ} \mathrm{C}-28^{\circ} \mathrm{C}$. Aradilla (2009) menyatakan bahwa Nyamuk Aedes sp. dapat hidup dengan baik pada suhu $24^{\circ} \mathrm{C}-39^{\circ} \mathrm{C}$ dan akan mati bila berada pada suhu $6^{\circ} \mathrm{C}$ dalam 24 jam. Hal tersebut masih memungkinkan nyamuk Aedes sp. untuk hidup dan melakukan aktivitas. Hasil penelitian pada malam hari diketahui masih ditemukannya nyamuk Aedes sp. yang menggigit tubuh umpan yaitu pada pukul 18.00
- 18.55 WIB sebanyak 3 ekor. Dimana suhu ruangan lokasi penelitian pada malam hari yang berkisar antara $26^{\circ} \mathrm{C}-27^{\circ} \mathrm{C}$ masih memungkinkan aktivitas menggigit nyamuk Aedes sp, karena suhu tersebut berada pada rentang minimun hingga optimum suhu yang sesuai bagi kehidupan nyamuk Aedes sp.

\section{KESIMPULAN}

Berdasarkan hasil penelitian dapat disimpulkan bahwa:

1. Nilai kelimpahan nisbi untuk kegiatan penangkapan di dalam rumah sebesar 7,28, sedangkan untuk kegiatan penangkapan di luar rumah sebesar 9,51.

2. Aktivitas menghisap darah nyamuk Aedes sp dimulai pukul 06.00 hingga pukul 18.55 WIB. Puncak aktivitas terjadi 2 kali, yaitu pukul $09.00-09.55$ dan pukul $16.00-16.55$ WIB. Terdapat 14 ekor nyamuk yang tertangkap di luar rumah dan 10 ekor nyamuk yang tertangkap di dalam rumah. Perilaku menghisap darah nyamuk Aedes sp di Kota Metro adalah anthropofilik.

\section{SARAN}

Adanya penelitian lanjutan tentang bionomik vektor dan studi ekologi tempat berkembangbiak nyamuk Aedes sp di daerah endemis di Kota Metro Lampung.

\section{DAFTAR RUJUKAN}

Aradilla, Ashry Sikka. 2009. Uji Efektifitas Larvasida Ekstrak Ethanol Daun Mimba (Azadirachta indica) terhadap Larva Aedes aegypti. Laporan Akhir Penelitian tidak diterbitkan. Semarang: Fakultas Kedokteran 
Universitas

Diponegoro

Semarang.

Departemen Kesehatan RI. Ditjen PPM \& PLP. 2001. Pedoman

Ekologi dan Aspek Perilaku Vektor. Jakarta.

Departemen Kesehatan RI, 2004. Tata Laksana Demam Berdarah Dengue. Jakarta.

Departemen Kesehatan RI. 2004. Kebijaksanaan Program P2DBD dan Situasi Terkini DBD di Indonesia. Jakarta.

Departemen Kesehatan Republik Indonesia. 2008. Kunci Identifikasi Nyamuk Aedes. Jakarta: Direktorat Jendral Pengendalian Penyakit dan Penyehatan Lingkungan. Jakarta.

Dinas Kesehatan Kota Metro. 2012. Laporan Kegiatan Program P2 DBD Kota Metro Bulan Januari s.d Desember Tahun 2007 - 2012. 10 Hal.

Dinas Kesehatan Kota Metro. 2013. Laporan Kegiatan Program P2 DBD Kota Metro Bulan Januari s.d Desember Tahun 2013 - April 2015. $6 \mathrm{Hal}$.

Dinas Kesehatan Kota Metro. 2013. Rencana Pembangunan Jangka Menengah Daerah (RPJMD) Kota Metro 2010-2015. Metro.

Hadi, Upik Kesumawati, Susi Soviana, Dwi Djayanti Gunandini. 2012. Aktivitas Nokturnal Vektor Demam Berdarah Dengue di Beberapa Daerah di Indonesia. Jurnal Entomologi Indonesia. Vol. 9, No. 1, April 2012 1-6. ISSN: 1829-7722.

Hasyimi, M., Nanny Harmany, Pangestu. 2009. TempatTempat Terkini yang disenangi untuk Perkembangbiakan Vektor Demam Berdarah Aedes aegypti. Media Litbang
Kesehatan. Volume XIX Nomor 2 Tahun 2009.

Gandahusada, Srisasi, Herry D. Ilahude DAP\&E, Pribadi Wita. 1998. Parasitologi Kedokteran. UI Press. Jakarta:

Sembel, Dantje T. 2009. Entomologi Kedokteran. Yogyakarta: CV. ANDI OFFSET

Sitio, Anton. 2008. Hubungan Perilaku Tentang Pemberantasan Sarang Nyamuk dan Kebiasaan Keluarga dengan Kejadian Demam Berdarah Dengue di Kecamatan Medan Perjuangan Kota Medan Tahun 2008. Tesis tidak diterbitkan. Semarang: Program Pasca Sarjana Universitas Diponegoro Semarang.

Supartha, I Wayan. 2008.

Pengendalian Terpadu Vektor Virus Demam Berdarah Dengue, Aedes aegypti (Linn.) dan Aedes albopictus (Skuse) (Diptera:Culicidae). Penelitian Ilmiah, 3-6 September 2008. Taki-Takining Sewaka Guna Widya. Hal: 1-5.

Veridiana, Ni Nyoman., Triwibowo, A.G.,Hayani, A., dkk. 2008. Pengamatan Indeks Jentik dan Tempat Perkembangbiakan Aedes aegypti di Kota Palu. Jurnal Vektor Penyakit. Lokalitbang P2B2 Donggala. Vol 2, No. 1, 1-7 hal. ISSN 1978-3647. 